\title{
Analyzing student teachers' use of theory in their reflections on mathematics teaching practice
}

\section{Wil Oonk ${ }^{1}$ (D) Nico Verloop ${ }^{2} \cdot$ Koeno P. E. Gravemeijer $^{3}$}

Received: 10 October 2018 / Revised: 28 April 2019 / Accepted: 7 May 2019 /

Published online: 4 July 2019

(C) The Author(s) 2019

\begin{abstract}
This study was conducted among 269 student teachers at 11 primary teacher training colleges in the Netherlands. To investigate their competence in integrating theory and practice in their reflections on mathematics teaching, a learning environment was designed to evoke theory use in reflections on practice. To be able to systematically describe the use of theory, we distinguished two dimensions, which we called the nature and level of theory use. A Reflection Analysis Instrument was used to univocally code the nature and level of the student teachers' theory use in the reflective notes of their final assessments into 1740 meaningful units. We found that nearly all student teachers used theory. However, they differed markedly in the way they linked theory and practice and with which depth they used theoretical concepts in their reflections. A remarkable finding of the study was the important influence of prior mathematics education on the nature and level of theory use, especially the low results of the third-year student teachers in their level of theory use. The outcome may have consequences for the design of the teacher education curricula and for the intake of first-year student teachers.
\end{abstract}

Keywords Mathematics teacher education - Multimedialearning environment - Nature and level of theory use . Theory and practice . Theory-enriched practical knowledge

Wil Oonk

0031630316853w.oonk@uu.nl

Nico Verloop

verloop@iclon.leidenuniv.nl

Koeno P. E. Gravemeijer

koeno@gravemeijer.nl

Extended author information available on the last page of the article 


\section{Introduction}

Interest in theory and theory building of research on and with mathematics teachers has been increasing in recent years, especially in the last decade (Da Ponte 2013; Lerman 2013; Sriraman and Kaiser 2006; Skott et al. 2013). Theory appears in many guises and at many levels (Silver and Herbst 2007). An important question for teacher education is how theories, especially local instruction theories (Gravemeijer 2004), can really be used by student teachers (STs) to deepen their thinking and reasoning about practice. For every theory, it is possible to select a set of coherent concepts that represent that theory. Such a set could provide participants in the discourse of practice with a vital vocabulary (Sfard 2008) to help them to learn to use theoretical concepts. ${ }^{1}$ Supporting STs in appropriating this vocabulary might enable them to integrate theory and existing practical knowledge into "Theory-enriched Practical Knowledge" (Oonk et al. 2004, 2015a). In this process, reflective thought is "a forceful motor" of mathematical discourse and invention (Freudenthal 1991, p.100). It is plausible that such a "motor" is effective and efficient if STs deepen their reflective thoughts with the use of adequate theory and that it will strengthen their own development. This resonates with Schön's notion of reflective practitioners (Schön 1983). Preparing STs to actually use theory, for example, "to move beyond a superficial 'right or wrong' analysis of tasks to a focus on how STs are thinking about the tasks" (National Council of Teachers of Mathematics 2000, p.24), is an important issue for teacher education. In their attempts to spark discussion about the question of how to prepare STs for future society, which means that STs are better equipped to understand the later thinking of students when completing tasks, Gravemeijer et al. (2017) emphasize that attention will have to be given in mathematics education to mathematics-specific forms of argumentation and communication. Their statements endorse the afore-mentioned suggestions about future teachers' professional development toward integrating theory and practice. In this study, we investigate STs' use of theoretical concepts in their written reflections on teaching practice. $^{2}$

The central problem is how the nature and the level of their theory use differs, also with regard to the relationship with their prior education and their year of study. To carry out this research, we created a practice-based multimedia learning environment that invites the use of theory. The research project is characteristic of the practice-based approach to elementary mathematics teacher education in the Netherlands (Goffree and Oonk 1999; Oonk et al. 2019).

\section{Theoretical considerations}

\section{Integrating theory and practice: bridging a "gap"?}

The failure of teacher education to influence teachers' practices has been described by a number of researchers (e.g., Ball 2000; Clark and Lampert 1986; Korthagen 2001, 2010; Vescio et al. 2008). For example, the approach in teacher education whereby STs

\footnotetext{
${ }^{1}$ We will use "the use of theoretical concepts" and "the use of theory" interchangeably.

${ }^{2}$ The data of this study were collected in 2004 and elaborated in 2018.
} 
learn theory during lectures and are then expected to apply it in practice still has not disappeared. Changing existing cultures remains difficult (Cohen 2011; Jaworski 2006; Lave 1996; Morris et al. 2009; Stigler and Hiebert 1999).

Conversely, the realization of well-considered teacher training goals can be impeded by the conformist influence that practical training can have on preservice teachers (Kaiser et al. 2007; Zeichner et al. 1987). Since the beginning of the last century, the research community has been working on "bridging the gap between theory and practice" (Cochran-Smith and Lytle 1999; Dewey 1904; Leikin and Levav-Waynberg 2007; Korthagen 2010) and "crossing boundaries" (Akkerman and Bakker 2011; Goos and Bennison 2018). This especially occurred in mathematics teaching, for example, by searching for practice-based theories of instruction intended to support STs in learning to teach students how to solve mathematical tasks that need deep, relational understanding (Cobb 1988; Cobb et al. 2003). Others have emphasized the development of concepts about what kind of knowledge is the key for future teachers (Ball et al. 2008; Nunes et al. 2016; Ruthven 2011). In the view of Freudenthal, "the Gap" between theory and practice "should not have to exist" (1987, p. 14). He considered the interaction between theory and practice as a process in which theory continuously influences practice. It supports understanding practice, improves practice, and grows itself in this way. In this sense, the aim of theory is not to be something "to apply" but a tool for understanding one's own and others' practice and to raise practice to a higher level. With this idea of level raising, Freudenthal (1991) saw a relationship between the theory and practice of learning and teaching and the level theory of Van Hiele (1973, 1986). In the original theory, Van Hiele (1973) described three levels in mathematical thinking. At level 0 , the base level, elements are judged only by their appearance. At level 1, elements are recognized by their properties, so a relation network exists. At level 2, relations between properties play an important part. Van Hiele's theory has been broadened to mathematics education (Gravemeijer 2004; Treffers 1987) and to teacher education in general (Korthagen 2010). Freudenthal saw reflection as having an important role within level theory, as a level-raising function, in the course of which reflection happens on a higher level on one's actions at the lower level (Freudenthal 1991, p. 101). In this way, reinvention of level raising leads to a natural merging of theory and practice. We agree with Freudenthal that a "gap" between theory and practice should not have to exist. It is not helpful to keep returning to the idea that theory and practice are totally different entities and "that in the organization of learning teaching, there is a 'gap' to be 'bridged"' (Lampert 2010, p. 31). Below, we will elaborate the implications of this view for the student teachers' process of integrating theory and practice.

\section{Theory-enriched practical knowledge}

In 1981, Elbaz introduced the concept of "teacher practical knowledge," "practical knowledge" for short, that can be defined as both the knowledge and the insights that underlie teachers' actions in practice. Within the term "practical knowledge," the word "knowledge" is used as an overarching, inclusive concept that summarizes a variety of cognitions from conscious and well-balanced opinions to subconscious and unreflected intuitions (Verloop 2001; Verloop et al. 2001; Oonk et al. 2015a). It does not mean that in this view, practical knowledge is in opposition to theoretical or scientific knowledge. 
Knowledge gained from lectures, self-instruction, and other sources of teacher education may be integrated into practical knowledge as well as the notion of pedagogical content knowledge, as developed by Shulman (1986). We consider the mathematical knowledge for teaching, distinguished by Ball et al. 2005, 2008; Nunes et al. 2016 or Ruthven 2011, used meanwhile by many other researchers (e.g., Keijzer and Kool 2012; Oonk et al. 2007), as the core of practical knowledge for mathematics teaching. Furthermore, practical knowledge is considered to have a narrative character (Clandinin and Connelly 1996; Lin 2002; Pendlebury 1995), because it often develops from stories of teaching practice. In a sense, this resonates with Freudenthal's didactical design idea that mathematical concepts can be derived by learners as they experience a need for those concepts, which asks the designer to generate situations in which phenomena need to be organized (Freudenthal 1983; Mor and Noss 2008). At the level of mathematics teacher education, such situations may evoke STs' use of theory. Oonk et al. (2004, 2015a) found that STs can acquire "theory-enriched practical knowledge" (TEPK), especially if it has to be constructed in appropriate situations. In this way, theoretical concepts (e.g. words, ideas) are meaningfully integrated within practical knowledge, in order to strengthen the STs process of theory use.

An illustration of how TEPK can come to the fore is described below in an excerpt in which a ST reflected on a video-recorded teaching situation with grade 2 students. The video clip shows the teacher talking with the children about the five times table visualized with ten tubes each containing five tennis balls, which are standing in front of the class.

The class has already come up with $2 \times 5$ followed by $3 \times 5$. Because the teacher visualizes the five times table for the children, they can also tell a story to accompany a problem. $1 \times 5$ can be seen as 1 tube times 5 balls. She also makes a connection between concrete material and a grid model. At one point, Clayton [pupil] is counting $10 \times 5$. The teacher confirms this for the class. In fact, a transition is being made here from multiplication by counting to structured multiplication.

The ST reasoned in this narrative reflection about the relationship between using manipulatives (the tennis balls in transparent tubes) and the higher level of the grid model. In her argumentation, she referred to concepts and instructional approaches (e.g., five times table, visualization, story to accompany a problem, concrete material, grid model, multiplication by counting, and structured multiplication) in a meaningful way and with mutual connections. In this way, the ST showed her TEPK about the STs' development of mathematical learning.

\section{The student teachers' process of enriching practical knowledge with theory}

The thesis that STs learning can be considered a process of enriching practical knowledge with theory is grounded in a series of assumptions (Oonk et al. 2004, 2015a).

Firstly, the process of enriching practical knowledge is a process of integrating theory with existing practical knowledge. Secondly, such a process is started and stimulated through discourse (Cobb et al. 2003; Ryve 2011). The STs actually go through a "process of appropriation" (Bakhtin 1981). The communication in this discourse could be considered as a "patterned collective activity" (Sfard 2008, p. 93), 
characterized by narratives representing practice with a specific vocabulary of specific concepts representing theory. The core in our view is that in such discourses, STs learn to use a suitable terminology in a meaningful manner (Oonk et al. 2015a). That means among other things that it is not easy to fulfill this process, because these words initially are the possessions of others, embodied by their beliefs, norms, and experiences. Thirdly, reflection on one's own and others' practices in particular can support STs in developing a coherent network of concepts - compare conceptual fields (Vergnaud 1983) - by using the various discourse elements (e.g., particular words and principles) in different ways. Reflection is a tool for analyzing what has happened and also a tool for anticipating situations. In that sense, reflection can be considered as a catalyst of "professional noticing," a concept that can be used to express the ability to recognize and act on key indicators significant to one's profession (Jacobs et al. 2010). STs' capacity to attend, interpret, and decide-three interrelated skills of professional noticing - could naturally enable them to develop a network of concepts for considering practice expertly. Researchers have suggested that professional noticing can be influenced through reflection on video-recorded representations of practice (e.g., Schack et al. 2013; Van Es and Sherin 2010). Fourthly, the narrative character of enriched practical knowledge will support STs to meaningfully learn to generalize and objectify concepts, ideas, and beliefs about teaching mathematics and, conversely, enable them to recall the meanings of subjects and ideas if necessary. Last but not least, the character of the theory that STs are assumed to use may influence the nature and the level of their theory use. The STs involved in the research that is reported here were expected to understand and apply the theory of Realistic Mathematics Education (RME) (Freudenthal 1973, 1991). At elementary teacher preparation colleges in the Netherlands, STs receive practical training in schools that teach, to varying degrees, in the spirit of RME. In teacher education, they are introduced to local instruction theories (Gravemeijer 2004), which have developed within the framework of the RME theory. A local instruction theory comprises theories about potential learning processes for a given topic and the means of supporting those learning processes. Such a theory offers a description of, and a rationale for, the envisioned learning route and the use of a series of instructional activities for a specific topic (e.g., addition and subtraction up to 100, fractions, area). Natural use of such a theory in practice demands knowledge and skills that exceed the local theory itself (e.g., orchestrating a productive classroom discussion and establishing and maintaining an inquiring classroom culture) and it also demands knowledge of the underlying domain-specific theory (Gravemeijer 2008). In this research project, STs were introduced to a local instruction theory on teaching multiplication (Ter Heege 1985; Van den Heuvel-Panhuizen 2001; Oonk et al. 2015a).

\section{The nature and level of theory use}

Previous research has provided us with constructs for identifying student teachers' use of theory, namely the nature and level of theory use (Oonk et al. 2015a). These constructs will help us to describe and to analyze STs' theory use in a systematic manner. The nature of theory use is defined as the way STs describe teaching situations with the aid of theory. Four categories or types of theory use can be distinguished (Fig. 1). These four categories form an inclusive relationship (i.e., B contains A, C contains $\mathrm{B}$, and so on). 


\section{Nature of theory use}

A. Factual description: The ST describes actual events only; no opinion is given, nor are any operations or expressions by either the teacher or the students explained.

B. Interpretation: The ST relates what he or she thinks happens without any supporting evidence or explanation (using indicator phrases such as I think or in my opinion).

C. Explanation: The ST explains why the teacher or students acts or thinks in a certain way. He/she gives an unambiguous, "neutral" explanation on the basis of (previously mentioned) facts or observed events (using indicator words or phrases such as for this reason, because, as, as if, probably, it could be possible that).

D. Response to situations: The ST relates or describes what could be done or thought (differently), what actions he or she, as stand-in for a virtual teacher, would take or want to take (using indicator phrases such as I expect, I predict, I would do, I make, I intend to, with the intention of ).

Fig. 1 Nature of theory use

The level of theory use indicates the extent to which STs use theoretical concepts and relations between concepts meaningfully. Four levels of theory use can be distinguished which increase in complexity (Fig. 2).

The main goal of this study was to gain insight into the STs' use of theoretical concepts in their reflections. We therefore investigated the following research question: In what way and to what extent do STs differ in their use of theory and how is this related to their prior education and their year of study?

To optimize the handling of data on the STs' theory use in the reflective notes of the final assessment, the general research question was divided into three sub-questions.

1. In what way do STs use theoretical knowledge when they describe practical situations after spending a period in a learning environment that invites the use of theory?

2. What is the theoretical quality of statements made by the STs when they describe practical situations?

3. To what extent is there a meaningful relationship between the nature and level of theory use and two variables: the STs' prior mathematics education and the STs' year of study?

\section{Level of theory use}

1. There is no recognition and use of a theoretical concept in the ST's utterances.

2. The ST recognizes theoretical concepts (correct description within a context; no network of concepts).

3. The ST describes junctions (meaningful relations) in a network of relations between concepts.

4. The ST reasons within the structure of a network of relations between concepts, developing a relation between relations.

Fig. 2 Level of theory use 


\section{Method}

\section{Context and participants}

Eleven 4-year elementary teacher preparation programs, with a total of 269 STs in groups of at least 10, participated in this study. The number of STs was actually determined by the 11 mathematics teacher educators who were voluntarily taking part in the research project. They were previously invited to participate at a conference of the network of experts involved in primary mathematics teaching in the Netherlands. In the Netherlands, the schools of education (Pabos) are part of colleges of higher vocational education. STs from first-, second-, and third-year groups from the fulltime and part-time courses, the dual course, and the shortened course (Table 1) were involved in the study. The group of 269 STs consisted of 249 women and 20 men between 18 and 20 years of age. The spread for gender, prior education, and type of course (full-time, part-time, dual, shortened) was comparable to that of the national population of Pabo STs. Their previous education varied from mbo level (senior secondary vocational education) to vwo level (pre-university education) and higher education. To answer our research question, we created a specific learning environment in order to optimize the chance of STs using the local instruction theory on teaching multiplication and to enable us to examine their theory use.

Table 1 Complete overview of the population

Number of STs per study year

Year 1

Year 2

Year 3

Total STs

Number of STs per type of course

Full-time

Part-time

Three year, dual

Three year shortened

Three year vwo

Total STs

Number of STs by prior education

Mbo without maths

Mbo with maths

Havo without maths

Havo with maths

Vwo without maths

Vwo with maths

Higher education

Other 
The STs were offered a course focused on learning to teach multiplication in grade 2 (Fig. 3). Video-recorded examples of practice, available in digital form, were an important part of their learning environment (see next section). The groups were taking the course that was offered as a part of the regular teacher preparation program. The STs were informed in advance of their participation in the national research project 'Theorie in Praktijk' (TIP - Theory in Practice).

The five, one-and-a-half hour, course meetings were directed by one of the 11 teacher educators. Part of the first meeting was used for an initial assessment; the fifth and final meeting contained a final assessment, which required an hour and a half extra. In total, the course consisted of 40 study hours, nine of which were contact hours with the teacher educator. One Pabo group offered the course as an option, giving the STs the choice of whether or not to follow it; in other groups, the teacher educator determined, in consultation with the researcher, how the course would best fit into the curriculum.

The teachers teaching the course were experienced teacher educators in at least the subject area Mathematics and Pedagogics; they had taken part in the training course that was developed within the framework of this study and taught by the researcher, i.e., the first author. The next section describes the learning environment of the STs and how the teacher educators were prepared to support them.

\section{The learning environment of the student teachers}

We created a learning environment which was expected to optimize the chance for STs to make use of theory and in which we could examine their theory use. The research literature describes a rich history of attempts to design this type of learning environment using the advantages of technology (Borko 2016; Brophy 2004; Gaudin and Chaliès 2015; Goldman et al. 2007; Herbst et al. 2011; Lampert and Ball 1998; Masingila and Doerr 2002; Sherin and Dyer 2017; Stockero 2008). The National Council of Teachers of Mathematics (2015) recommends that technology be used strategically, because this strengthens mathematics teaching and learning (Dick and Hollebrands 2011). Strategic use assumes a directed use of technology, especially within the context of instruction, but this does not mean continuous use of technology.

The design of the learning environment for the STs who participated in this largescale study was adapted from initial studies of multimedia interactive learning environments (Dolk et al. 1996; Goffree and Oonk 2001; Oonk et al. 2004). It was largely similar to the STs' learning environment in the earlier exploratory case study (Oonk et al. 2015a), which roughly means an environment centered on a set of teaching narratives suitable for multiplication instruction in grade 2 . The narratives were organized in a digital format, referred to as "the Guide" (Goffree et al. 2003), encompassing 25 video clips (e.g., excerpts of lessons, interviews with children, teacher interviews) with related text (e.g., protocols of class discussions and diagnostic talks, teachers' reflections on lesson preparation and evaluation, STs' worksheets). The narratives were organized into 12 themes, which were formatted as questions (e.g., How do I start teaching multiplication? How can I use materials? How do STs differ? How do I organize a class discussion?). Each of the 25 narratives was accompanied by an expert reflective note, representing the theoretical background of the local instruction theory for multiplication. These notes provided STs with a written analysis of what they could 
Meeting 1: Initial assessment and course introduction

- Initial assessment: responding to four video-recorded teaching situations (supervised)

- Introduction to the program.

- $\quad$ Filling in list of concepts (individual, 30 minutes; form of list comparable to list in Appendix).

- Independent study: becoming familiar with the Guide.

\section{Meeting 2: The Guide and the personal learning question}

- Discussion about their first experiences with the Guide under the direction of the teacher educator.

- Individual notes: 'What did you learn?'

- $\quad$ Thinking up and formulating a personal learning question: introduction by teacher educator; plenary discussion.

- Independent study with the aid of the Guide and writing a commentary on a personally selected teaching narrative.

- $\quad$ Elaborating the personal learning question.

\section{Meeting 3: Cooperative lecture and discussion about acquiring ST's network of tables of} multiplication

- Analysis and discussion about two primary school STs' knowledge of the tables of multiplication; video-recorded interviews with STs Paul and Necmiye as a starting point.

- Preparatory instruction for an investigation by STs into primary school STs' network of tables of multiplication.

- Cooperative lecture: overview of the four stages of the learning trajectory for multiplication as a theoretical reflection on the practical situations discussed in the Guide.

- Individual notes: 'What did you learn?'

- Independent study: with the aid of the Guide; continuing to work individually and in small groups on the personal learning question. Preparing and elaborating an investigation of a ST's times table network on the field placement.

\section{Meeting 4: Game of concepts}

- Game of concepts: reflective group discussion directed by the teacher educator, about the possible connection between given theoretical concepts and four teaching situations.

- Individual notes: 'What did you learn?'

- Independent study: continuing to work individually and in small groups on the personal learning question and, elaborating the investigation of a ST's times table network on the field placement.

\section{Meeting 5: Final assessment (supervised)}

- $\quad$ Filling in the list of concepts: which concepts have gained meaning (see Appendix).

- Writing a reflective note for an unknown situation (video).

- Hand in final assessment and report on teaching practice.

Fig. 3 Overview of the activities during the five meetings of the course 
observe in the video and of what the teacher or the pupils might have considered doing. Relevant theoretical concepts, schemes, and perspectives for teaching ideas were incorporated meaningfully into the text. An important integral component of the guide was a vocabulary presented as a collection of 59 concepts covering the local instruction theory on teaching multiplication in grades 1 and 2. The concepts (e.g., manipulatives, exercizing, memorizing, commutative property, diagnosis, explaining, model, core objectives, learning strand) originated from the 25 expert reflections on the video clips. They were formatted in the reflective notes as interactive links to provide STs with additional information. The concepts were developed by the team of experts who wrote the reflections, including the first author of this article. The criterion for selection was conformity with the concepts used in the Dutch Learning-Teaching Trajectory for mathematics teaching (Van den Heuvel-Panhuizen 2001) and in the standards for mathematics teacher education (Goffree and Dolk 1995).

A few components of the learning environment were adapted or added based on experiences from the small-scale study (Oonk et al. 2015a). This involved, for example, the initial assessment (see "The instruments" section) and a "logbook activity" — entitled "What (else) did you learn in this meeting?"- - designed to make STs even more aware of their own learning or increase in learning. The teacher educators were provided with a detailed manual and were given a day of training (see next section). The stated assumption was that, with these adaptations and additions to the learning environment as used in the small-scale study, the STs' use of theory could be optimized.

\section{Training the teacher educators}

Primary mathematics teacher educators in the Netherlands have formed a close network since the 1970s, resulting, among other things, in a considerable consensus of opinion about learning to teach mathematics (Goffree and Dolk 1995; Goffree and Oonk 1999, 2001; Oonk et al. 2019). At the annual conference of the network, the first author of this article provided information about the content of this research project as well as information about the conditions for participation in the study.These conditions were the mandatory and conscientious use of the course materials offered, including the course in the regular curriculum; mandatory training for teacher educators; certification; at least 2-year experience as a mathematics teacher educator; the size of ST groups; the number of meetings; and the number of contact hours. These conditions were mentioned again in the flyer that was handed out at the conference and distributed electronically over the national network. The 12 Pabos that participated showed a geographic spread across the Netherlands. One Pabo dropped out during the study due to organizational problems.

A mandatory day of training for the teacher educator in advance of the study was organized under supervision of the first author. The goal of the training was to optimize the analogy with working with STs by the various teacher educators. Results from the earlier development and research were used to inform teacher educators about how to introduce the Guide as a tool for the discourse and how to create an appropriate investigation context for student teachers. The information was described in a teacher educator's manual. The manual contained detailed guidelines for each meeting. These guidelines concerned the goals of the meeting, the organization, the subject-specific and course-pedagogical content, suggestions for the STs and aspects that were vital for 
obtaining valid research data, such as the exact instruction for filling in the lists of concepts and handing out the assignments for the assessments.

\section{The instruments}

\section{Initial assessment}

The reflective note at the start of the course was intended to test the level at which the STs used theory within a specific category of the nature of theory use (factual description, interpretation, explanation and response to situations) (see the section above on the nature and level of theory use). The four assignments for four different video-recorded teaching situations had been phrased so that they would evoke these four types of theory use in turn. For instance, in the first assignment, the STs were asked to observe student Chantal and then, in their own words, give a factual description of what occurred in that situation. This part of the initial assessment yielded two types of data: primarily the number of theoretical concepts that each ST used in doing the assignments and also statements by STs in which theoretical concepts were used.

\section{Final assessment}

The four practical situations presented in the video material and the situation for the final assessment were selected from the lessons about learning the multiplication tables in grade 2, with the same students and teachers for all situations. The situation that was selected for the final assessment was new to the STs. They were given a short explanation about the context of the situation and where the video clip of the situation could be found; there was also some advice on writing the reflection. The large scale of the study necessitated limiting the use of tools and data to those of the written reflections in the initial and final assessments.

\section{Procedure and data collection}

The initial assessment was done during the first meeting of the course offered to the STs, with the purpose of determining the number of theoretical concepts used, as well as the level per category for the nature of theory use (factual description, interpretation, explanation, response to situations). For the number of concepts, a distinction was made into the total amount of concepts, the number of different concepts, the number of pedagogical content concepts, and the number of general pedagogical concepts.

The final assessment was performed in the final meeting of the course. This established the nature and level of theory use at the end of the course, as well as the number of theoretical concepts used. Just as for the initial assessment, subcategories were created for the number of concepts, the number of different concepts, the number of pedagogical content concepts, and the number of general pedagogical concepts.

The following variables served as background variables: the institute (the Pabo) at which the ST studied; the ST's prior education; the kind of course the ST was taking (fulltime, part-time, shortened); the study year; the group (class) the ST was in; small or large group; gender; and the primary school group in which the STs did their teaching practice. 


\section{Analysis}

\section{Reflection analysis instrument}

The constructs of nature of theory use and level of theory use (Figs. 1 and 2) formed the Reflection Analysis Instrument (Oonk et al. 2015a) with which the theory use of the 269 STs was analyzed. The reflective notes from the initial assessment and, especially, from the final assessment functioned as the sources of data.

The STs' reflective notes were structured into meaningful units (see examples in Fig. 4): a meaningful unit in the form of a paragraph on a subject or a theme (Bales 1951; Krippendorff 2004). The meaningful units consisted of completed stories, trains of reasoning, or thoughts about an occurrence, or could be distinguished by transitions in the type of theory use, for instance from factual description to interpretation of the situation being observed.

Where possible, the structure imposed on the text by the ST was taken into account. Sometimes, the units to be distinguished were already visible through white space or paragraph demarcations. Syntax also offered support for separating text into meaningful units. For example, words such as "furthermore" or "also" were often indications that a sentence should be part of a preceding sentence or paragraph. When there was doubt about unitizing a text, we chose to keep the text as one single unit.

The theoretical concepts were not only identified in the literal senses (the 59 indicated concepts), but also conceptually, as synonyms or descriptions with the same meaning as the "mother concept," depending on how the STs used these "derived concepts" meaningfully within the given context.

The discussions about validating the identification and coding of the meaningful units occurred during two sessions between the first author and a second expert.

The conversations were transcribed. Using a random sample of 15 STs out of 269 i.e., amply 5\% for statistical reasons with regard to weighing requirements for practicability versus representativeness - the interrater reliability was determined at $81 \%$. The discussion on the remaining differences led to full agreement between the experts.

The Reflection Analysis Instrument (Figs. 1 and 2) for coding and categorizing the nature and level of theory use (see examples in Fig. 4) was tested to determine the interrater reliability. The Cohen's Kappa coefficients (Cohen 1960) ${ }^{3}$ for the nature and the level of theory use were .80 and .86 , respectively. For the combination of nature and level, the outcome was $\kappa=.77$.

\section{The data}

The data collected in this study came from 269 STs spread over 11 Pabos. Following the procedure described earlier, the initial assessment was scored for level of theory use and the final assessment for nature and level of theory use. The initial assessment consisted of four situations, each aimed at one of the categories for nature of theory use, thus four meaningful units per ST, i.e., $269 \times 4=1076$ units. For scoring purposes, the final assessments were divided into 1740 meaningful units, on average seven units per ST (Table 2). For nature as well as level of theory use, each ST was scored on the number of theoretical concepts used.

\footnotetext{
$\overline{3}$ Percentage agreement is widely used, but may be misleading.
} 


\begin{tabular}{|c|c|c|}
\hline $\begin{array}{l}\text { Example of } \\
\text { Meaningful Unit }\end{array}$ & $\begin{array}{l}\text { Nature of } \\
\text { Theory Use }\end{array}$ & $\begin{array}{l}\text { Level of } \\
\text { Theory Use }\end{array}$ \\
\hline $\begin{array}{l}\text { Teacher Minke starts the lesson with } \\
\text { telling a story about the present for the } \\
\text { class (suitcase with tennis balls). }\end{array}$ & $\begin{array}{l}\text { This is a description } \\
\text { of what the ST observed. } \\
\text { (A: Factual description) }\end{array}$ & $\begin{array}{l}\text { No theoretical concept is } \\
\text { used. } \\
\text { (Level 1) }\end{array}$ \\
\hline $\begin{array}{l}\text { Fariet [student] used a strategy of } \\
\text { counting by tens. It's a way of thinking } \\
\text { that makes sense. }\end{array}$ & $\begin{array}{l}\text { The second sentence points } \\
\text { toward an interpretation of } \\
\text { the situation. } \\
\text { (B: Interpretation) }\end{array}$ & $\begin{array}{l}\text { One theoretical concept } \\
\text { (strategy) is used. No } \\
\text { meaningful relationship } \\
\text { between concepts is } \\
\text { constructed. (Level 2) }\end{array}$ \\
\hline $\begin{array}{l}\text { With the concrete material [tennis } \\
\text { balls] Minke [the teacher] visualizes } \\
\text { the five times table for the students. } \\
\text { Because of the grid model thus come } \\
\text { into being, Clayton can invent the } \\
\text { strategy of structured multiplication } \\
10 x 5 \text {, starting from counting the fives. }\end{array}$ & $\begin{array}{l}\text { The text has the character of } \\
\text { an explanatory } \\
\text { description,with the signal } \\
\text { words"because" and "thus" } \\
\text { (C: Explanation) }\end{array}$ & $\begin{array}{l}\text { Six concepts are used in } \\
\text { mutual connection ( } \\
\text { concrete material, } \\
\text { visualizes, five times table, } \\
\text { model, strategy, and } \\
\text { structured multiplication). } \\
\text { Concepts are meaningfully } \\
\text { related. (Level 3) }\end{array}$ \\
\hline $\begin{array}{l}\text { The strategy of counting three } \\
\text { rows of five tiles using the rectangle } \\
\text { model, shows the student each of the } \\
\text { fifteen tiles in a multiplicative } \\
\text { structure. However, this is a lower } \\
\text { level than the strategy of the } \\
\text { multiplication by three jumps on the } \\
\text { numberline model. I think the teacher } \\
\text { could stimulate this last level for some } \\
\text { students, to bring them more fast to } \\
\text { formal multiplication. }\end{array}$ & $\begin{array}{l}\text { The ST anticipates the } \\
\text { situation in terms of a } \\
\text { possible alternative to the } \\
\text { teacher's approach. } \\
\text { (D: Response to situations) }\end{array}$ & $\begin{array}{l}\text { The ST develops a } \\
\text { relationship (models on } \\
\text { different levels) within the } \\
\text { network of relations } \\
\text { between the concepts: } \\
\text { rectangle model as a "model } \\
\text { of", multiplicative structure, } \\
\text { strategy, the numberline as } \\
\text { a "model for", } \\
\text { to multiply by jumping, and } \\
\text { formal multiplication. } \\
\text { (Level 4) }\end{array}$ \\
\hline
\end{tabular}

Fig. 4 Examples of data nature and level of theory use (see definitions in Figs. 1 and 2)

\section{Results}

The general research question was: In what way and to what extent do STs differ in their use of theory and how is this related to their prior education and their year of study?

In the following sections, we discuss the results of the three sub-questions. 
Table 2 Statistics units in final assessment

$\begin{array}{lr}\text { Number valid STs } & 246 \\ \text { Number missing STs } & 23 \\ \text { Number meaningful units } & 1740 \\ \text { Mean } & 7.07 \\ \text { Median } & 7.00 \\ \text { Mode } & 6 \\ \text { Std. deviation } & 1.79 \\ \text { Minimum } & 4 \\ \text { Maximum } & 13\end{array}$

\section{The first research question}

The first results concerned the nature of theory use: In what way did STs use theoretical knowledge when they were describing practical situations after spending a period in a learning environment that invited the use of theory? The results show that the 1740 meaningful units that were observed could be categorized as involving the nature of theory use, of which $25 \%$ concerned factual description (A), $12 \%$ interpretation (B), $42 \%$ explanation, and $21 \%$ response to situations(D) (see Table 3 ).

Because the percentages for the four categories are the average percentages scored by STs (with standard deviations of 18 to $28 \%$ ), and not percentages of the population or numbers of STs per category, we also looked at STs for whom $\geq 50 \%$ of their meaningful units proved to belong to one specific category (Table 4).

We found that about $81 \%$ of the STs mainly used $(\geq 50 \%)$ one of the four categories. Furthermore, the ranking of the categories (Table 4) matched that of the categories in Table 3 . Here too, the relatively high percentage of the category explanation (Cat. $\mathrm{C}$ $44 \%$ ) stands out.

\section{The second research question}

The second research question concerned the level of theory use: What was the theoretical quality of statements made by the STs when they were describing practical situations?

It was reasonable to predict that the average percentage for level 4 would be the lowest, simply because level 4 was the hardest to reach. Indeed, Table 5 shows that

Table 3 Number of meaningful units in the final assessments of the STs that could be allocated to the four categories for the nature of theory use. Number of STs: 246. Total number of meaningful units: 1740

\begin{tabular}{|c|c|c|c|c|}
\hline & $\begin{array}{l}\text { Factual description } \\
\text { (Cat. A) }\end{array}$ & $\begin{array}{l}\text { Interpretation } \\
\text { (Cat. B) }\end{array}$ & $\begin{array}{l}\text { Explanation } \\
\text { (Cat. C) }\end{array}$ & $\begin{array}{l}\text { Response to } \\
\text { situations (Cat. D) }\end{array}$ \\
\hline Number of meaningful units & 440 & 202 & 730 & 368 \\
\hline Mean per ST (St. Dev.) & $1.8(1.8)$ & $0.8(1.3)$ & $3.0(2.0)$ & $1.5(1.5)$ \\
\hline Mean percentage per ST (St. Dev.) & $25(25)$ & $12(18)$ & $42(28)$ & $21(21)$ \\
\hline
\end{tabular}


Table 4 Number of STs in the final assessments that mainly used ( $\geq 50 \%)$ one of the four categories for nature of theory use. Number of STs: 239. Total number of meaningful units: 1740

\begin{tabular}{lllll}
\hline & $\begin{array}{l}\text { Factual description } \\
\text { Cat. A } \geq 50 \%\end{array}$ & $\begin{array}{l}\text { Interpretation Cat. } \\
\mathrm{B} \geq 50 \%\end{array}$ & $\begin{array}{l}\text { Explanation Cat. } \\
\mathrm{C} \geq 50 \%\end{array}$ & $\begin{array}{l}\text { Response to situations } \\
\text { Cat. D } \geq 50 \%\end{array}$ \\
\hline $\begin{array}{c}\text { Number of STs } \\
\begin{array}{c}\text { Percentage of total } \\
\text { number STs }\end{array}\end{array}$ & 18 & 16 & 104 & 28 \\
\hline
\end{tabular}

none of the 1740 meaningful units of the final assessment was scored at the fourth level. We elaborate on this finding in the conclusion section. Descriptive analysis of the levels reveals that the average percentages of the other three levels were not far apart, with an average of $35 \%, 29 \%$, and $36 \%$ for levels 1, 2, and 3, respectively. The average percentage for level 3 was higher than expected. That higher percentage may have been caused by the relatively large number of second- and third-year STs or the percentage of the ST population with a relatively high level of prior mathematics education. For the same reasons as for the nature of theory use, here too, we looked at STs for whom $\geq$ $50 \%$ of their meaningful units proved to belong to one specific level of theory use.

We found that about $76 \%$ of the STs mainly used one of the three categories of levels. Here, the ranking of the percentages $\geq 50 \%$ (Table 6) matched that of the percentages in Table 5 for the levels 1 and 3 .

\section{The third research question}

The third research question was: To what extent is there a meaningful relationship between the components of theory use and the variables STs' prior mathematics education or STs' year of study?

It is plausible to expect that a higher level of prior mathematics education would be to the advantage of STs when reflecting on situations compared to STs with a lower level of prior mathematics education. Given the differences between curricula, we expect students with higher level of prior mathematics education to have more content knowledge (for example compare mbo with- and without mathematics, see Tables 1 and 7). Furthermore, STs in later study years may have a larger repertoire of concepts than STs in earlier years of study. We also expected the relationship between the number of concepts and the level of theory use to manifest itself more strongly in the final assessment than in the initial one, as the students had by then had the opportunity to expand their repertoire within the learning environment of the course. Finally, it is

Table 5 Number of meaningful units in the final assessments of the STs that could be allocated to the four categories for level of theory use. Number of STs: 246. Total number of meaningful units: 1740

\begin{tabular}{lllll}
\hline & Level 1 & Level 2 & Level 3 & Level 4 \\
\hline Number of meaningful units & 603 & 512 & 625 & 0 \\
Mean per ST (St. Dev.) & $2.4(1.8)$ & $2.1(1.3)$ & $2.5(1.8)$ & 0 \\
Mean percentage per ST & 35 & 2 & 36 & 0 \\
\hline
\end{tabular}


Table 6 Number of STs in the final assessments that mainly used $(\geq 50 \%)$ one of the four categories for level of theory use. Total number of STs: 246

\begin{tabular}{lllll}
\hline & $\begin{array}{l}\text { Percentage level } \\
1 \geq 50 \%\end{array}$ & $\begin{array}{l}\text { Percentage level } \\
2 \geq 50 \%\end{array}$ & $\begin{array}{l}\text { Percentage level } \\
3 \geq 50 \%\end{array}$ & $\begin{array}{l}\text { Percentage level } \\
4 \geq 50 \%\end{array}$ \\
\hline Number of STs & 73 & 38 & 73 & 0 \\
Percentage of total number & 30 & 16 & 30 & 0 \\
STs (239) & & & \\
\hline
\end{tabular}

known from the literature that teachers who have less content knowledge are more oriented on facts and procedures, while teachers who possess a larger repertoire of content knowledge are more inclined to look for conceptual and problem-solving aspects (Putnam and Borko 1997).

Realizing these expectations and considering the results of the previous research questions, we assume that STs who have a higher level of prior mathematics education would more often tend to explain, to respond to situations, or to reason at level 3, while, on the other hand, factual description and interpreting or reasoning at levels 1 or 2

Table 7 Correlation between nature of theory use and prior education

Beta

$-0.131$

0.041

Percentage factual description and prior education

$-0.195$

0.003

Percentage factual description $\geq 50$ and prior education

0.130

0.041

Percentage factual description $\geq 50$ and mbo without math

0.160

0.013

Percentage factual description and vwo with mathematics

$-0.099$

0.127

Percentage factual description $\geq 50$ and vwo with mathematics

$-0.106$

0.103

Correlation interpretation (B) and prior education

Percentage interpretation and prior education

$-0.129$

0.043

Percentage interpretation $\geq 50$ and prior education

$-0.042$

0.514

Percentage interpretation and mbo without mathematics

0.092

0.151

Percentage interpretation and vwo with mathematics

$-0.043$

0.498

Correlation explanation (C) and prior education

Percentage explanation and prior education

0.000

Percentage explanation $\geq 50$ and prior education

0.275

0.000

Percentage explanation and mbo without mathematics

$-0.202$

0.001

Percentage explanation $\geq 50$ and mbo without mathematics

Percentage explanation and vwo with mathematics

$-0.246$

0.000

0.138

0.031

Percentage explanation $\geq 50$ and vwo with mathematics

0.149

0.021

Percentage responding (D) and prior education

Percentage responding and prior education

$-0.051$

0.426

Percentage responding $\geq 50$ and prior education
$-0.037$

0.573 
would mostly correlate with a lower level of prior mathematics education. The same characteristics applied to STs in the third study year as to STs in the first and second year of their study.

Linear regression analysis confirmed most of the assumptions above. Furthermore, as expected, we found a significant positive correlation between the number of concepts and level three of theory use $(p<0.05)$, also for the different theoretical concepts used, all of them part of the vocabulary of 59 concepts (see Appendix). A stronger relationship was recorded between the number of concepts and the level of theory use in the final assessment than in the initial one. Notable was the strong positive correlation between explanation and the number of general pedagogical concepts but the absence of any correlation between explanation and the number of pedagogical content concepts used. The content-related differences and the difference in reach between general pedagogical and pedagogical content concepts may have played a part. STs tend to initially respond in general terms to teaching situations. This is understandable, since the general pedagogical vocabulary is aimed more at the whole of the pedagogical-didactical actions of teacher and students, and is also used more frequently in teacher training and practice.

A remarkable exception to the assumption that STs who have a higher level of prior mathematics education would more often tend to respond to situations concerned the category response to situations (D) (Table 7). The possible cause of that deviation may be the relative low number of STs with a higher level of prior mathematics education (Table 1).

A second exception was the unexpected strong significant positive correlation between level three and study year 2 and the significant negative correlation between level three and study year 3 (Table 8). These results can be explained by the different levels of prior mathematics education: for the second year STs, 57\% at the highest level and $19 \%$ at the lowest level; and for the third year STs, $42 \%$ at the highest level and

Table 8 Correlation level of theory use and study year

\begin{tabular}{lcr}
\hline & Beta & Sig. \\
\hline Correlation level 1 and study year & & 0.153 \\
Percentage level 1 and study year 1 & 0.170 & 0.017 \\
Percentage level $1 \geq 50$ and study year 1 & -0.187 & 0.008 \\
Percentage level 1 and study year 2 & -0.159 & 0.003 \\
Percentage level $1 \geq 50$ and study year 2 & 0.062 & 0.013 \\
Percentage level 1 and study year 3 & 0.034 & 0.329 \\
Percentage level $1 \geq 50$ and study year 3 & & 0.601 \\
Correlation level 3 and study year & -0.124 & 0.053 \\
Percentage level 3 and study year 1 & -0.078 & 0.220 \\
Percentage level $3 \geq 50$ and study year 1 & 0.221 & 0.000 \\
Percentage level 3 and study year 2 & 0.253 & 0.000 \\
Percentage level $3 \geq 50$ and study year 2 & -0.115 & 0.072 \\
Percentage level 3 and study year 3 & -0.141 & 0.027 \\
Percentage level $3 \geq 50$ and study year 3 & &
\end{tabular}


$31 \%$ at the lowest level. This is consistent with our findings on the correlation between the level of prior mathematics education and study year 3 (Table 7) and between explanation (Cat. C) and study year 3 (Sig. 0.013; beta -0.157).

\section{Conclusion and discussion}

To investigate STs' competence in integrating theory and practice of mathematics teaching, a learning environment was designed to evoke theory use in their reflections on practice. We distinguished two dimensions of theory use: the nature and level of theory use.

\section{Theory and practice: enriching practical knowledge}

First of all, the study showed that each meaningful unit in the STs' final assessment, in total 1740 and on average seven per ST, could be interpreted using one of the characteristics for nature, and one of the characteristics for level of theory use. Nearly all STs, $98 \%$ of the population, used theory in their final assessment, on average 12 theoretical concepts per ST, which means that most STs were able to relate theory and practice in the context of the learning environment offered.

What does this result mean for the STs' competence in integrating theory and practice, that is, their competence in acquiring theory-enriched practical knowledge (TEPK)? Considering the process of enriching practical knowledge as a process of increasingly integrating theory with existing practical knowledge, we found a spectrum of theory use from STs. This ranged from STs who described zero meaningful units with a theoretical concept in the reflective note of their final assessment (3 STs out of 246 ), to STs for whom we categorized $\geq 50 \%$ of the meaningful units in their assessment as level 3 of theory use (73 STs out of 246). This level of theory use can be understood as practical theorizing (Ruthven 2001) or what Simon (1995) considers as the beginning of developing a hypothetical learning trajectory.

What stood out was the absence of any meaningful units that could be adjudged to be level 4 of theory use. This means that none of the 246 STs' reflective notes showed developing a new relation between relations within the structure of a network of relations between concepts. This result is consistent with earlier findings. However, Oonk et al. (2015a) found that while theory use did not occur at level four in the written reflections, it really did happen during video stimulated recall interviews. Expressing thoughts that integrate theoretical concepts in writing appears to be something that requires more or other specific skills than is the case for thoughts that are expressed orally during interaction and interviews. The yield of oral reflections is often higher than that of written ones (Jaworski 2006). Theory use may be particularly evoked by activities where oral input is natural. This argues in favor of a variety of written and oral activities, also in assessments.

Another striking finding of this study was the important influence of prior mathematics education on the nature and level of theory use, especially the low results of the third year STs in their use of theory at level 3. This is all the more remarkable because the local instruction theory offered on teaching multiplication was relatively easy compared with other theories, for example the theory on teaching fractions. The 
outcome may have consequences for the design of the teacher education curricula and for the intake of first-year STs (see next section).

This study was limited to a certain extent by choices that were made. One example of a limitation was the context in which the study was conducted. It was not the STs' own teaching practice that was at the center of the study, but "practice" for the student teachers consisted mainly of practice situations that were represented in multimedia form. Despite all the advantages of the multimedia practice, for example professional development (Gaudin and Chaliès 2015), theoretical enrichment (Oonk et al. 2004), opportunities for learning (Sherin and Dyer 2017), or the development of a reflective stance (Stockero 2008), the question remains whether situations from the student teachers' own practice as an object of discussion and reflection would not have led to a better insight into making connections between theory and practice. It is possible that focusing on their own practice may have helped the STs to successfully go through the "process of appropriation" (Bakhtin 1981) of TEPK. Many student teachers forget the theory presented at university and revert to the "norm" of behavior in that school, or department. However, it is just in the real practice of teaching that STs can become particularly aware of theory as a necessary instrument for reflection on their thinking and actions, with as its goal understanding and responding adequately to situations.

Another example of the limitations of this study was in the collection of data. The nature of the data collection, mainly consisting of reflective notes, may have limited the STs' insight into some aspects of the use of theory.

\section{Implications for teacher education}

We found that most of the STs in this study integrate theory and practice in a natural way by acquiring "theory-enriched practical knowledge" (TEPK) if they are in an adequately equipped multimedia learning environment, aimed at integrating theory and practice. The learning environment in this study was, for a variety of reasons, a vital component of the teacher education curriculum offered: vital because it enabled STs to become conscious of phenomena of real teaching practice and to acquire TEKP in a way they could rarely experience in their own teaching practice. Some characteristics of this multimedia learning environment (MLE) could qualify for general application in MLEs for teacher education. First, STs could freely surf in a conveniently arranged, "rich" collection of video-recorded real teaching practices around the course theme, together with expert reflections on these practices. Former studies (e.g., Brophy 2004; Goldman et al. 2007; Lampert and Ball 1998) have shown that STs need a clear view to survey the environment; the recorded teaching practices alone will not naturally prompt them to use theory. New visions on using digital tools may provide ideas about the integration of digital technology in teaching and learning (Drijvers 2019; Kang and Van Es 2018). Second, the vocabulary of 59 concepts covering the local instruction theory of the theme in this study (teaching multiplication) was a tool that supported STs at different levels. It was a dictionary in all parts of the course and an advance organizer (Ausubel 1968). It also served as a tool to gauge their learning process when they indicated in a special format (see Appendix) which concepts were known or unknown to them and which were meaningful in the context of a practice story and the source of that story (own practice, literature, videoclips, lectures, and workshops). Third, the study showed that the role of the teacher educator is crucial to stimulating 
improvements in level. The teacher educator has the expertise to theorize, to evoke, and to stimulate theory use, by for instance selecting adequate video fragments, asking challenging questions, making use of differences in argumentations, presenting confronting situations (Piaget 1974) and inspiring pedagogical conflicts, sharpening the discourse with theory-laden summaries, or by stimulating hypothetical thinking (Simon 1995). It is precisely the combination of these ingredients that can lead STs to expand their own repertoire through assimilation of the experts' TEPK and through "adaptation and accommodation" (Oonk et al. 2004, p.152) enlarging their own repertoire by modifying the experts' repertoire.

The training for the teacher educators provided them with knowledge and skills to enable them to perform the activities discussed, for example to serve as a model to "orchestrate" (Cobb et al. 2003) the discourse in class meetings (Kilpatrick et al. 2001). This included supporting the STs in using the set of 59 theoretical concepts as a vital vocabulary (Sfard 2008) for their thinking and reasoning about the teaching practice presented on the video. In doing so, they made hidden practical knowledge explicit and enriched it with theory aimed at acquiring a network of relations among concepts, i.e., acquiring TEPK. Such networks may be comparable with what Vergnaud (1983) describes as the context in which students learn in terms of "mastering situations" to produce a mastered collection of situations which he calls a "conceptual field." The learner (e.g., maths student) "masters" a conceptual field if he or she masters several concepts of a different nature. Lampert (2001) applies the idea of "conceptual field" not just to learning but also to teaching. She considers her teaching approach as facing students with conceptual fields. In this study, STs had to acquire a rather complex "field," a kind of "conceptual web," as a web of relations among relations between 59 concepts.

The ST's own teaching practice was part of the ST's course activity, but the focus in this study was on analyzing and discussing representations of practice. However, these activities can have a positive influence on STs' attitude to mathematics (Oonk and De Goeij 2006) and their teaching practice. They may support STs to elicit and respond to students' ideas and to learn how to enact aspects of practice in complex situations, activities that can be improved through theoretical reflection on their practice. Pedagogies of investigation and of enactment are necessary if teachers are to develop classroom practices that focus on student reasoning (Grossman et al. 2009), especially if they are to scaffold students' language required for mathematical learning (Smit et al. 2016).

The approach of integrating theory and practice, as demonstrated in this study, has been incorporated into a series of five books for primary mathematics teacher education in the Netherlands. In these books, teaching practices are the starting point for theoretical reflections and tools to recall in the discourse, lists of concepts are means for teacher educators and STs to support and to judge the processes of learning to integrate theory and practice and, an accompanying website provides STs and teacher educators with access to video episodes, tasks, and guides (e.g., Oonk et al. 2015b, 2017). The STs and teacher educators involved appreciate learning and teaching in this way. However, it demands a high level of "doing and understanding".

To really support the integration of theory and practice, we have to rethink our vision on learning and teaching mathematics, for example to discuss the need for a theory of reflective practice that enriches practice with theoretical knowledge. But this is not the 
only effort we have to make. Gravemeijer et al. (2017) answered the question of how mathematics education might prepare students for the society of the future with a list of propositions. Their proposition that choosing to aim for twenty-first century skills and high-level conceptual understanding requires a significant effort in teacher professionalization, curriculum design, and test design serves as an incentive. It may encourage the design of learning environments that students, student teachers, and teacher educators evoke to invent "conceptual fields" (Vergnaud 1983) at different levels of learning and teaching mathematics.

\section{Appendix. The Vocabulary shaped like a list of concepts}

Name student teacher:

Class:

Name Pabo:

The concepts given below are key concepts from the teaching method for learning to multiply. You filled in the list at the start of the course to indicate which concepts did or did not mean anything to you and for which concepts you believed you knew a teaching narrative. Now, at the end of the course, you are asked to indicate which concepts have become more familiar to you as a result of the course, and now mean enough to you that you can relate a teaching situation or a teaching narrative in which you could explain these concepts to others.

Use the list you filled in at the start of the course as a comparison. In the list below, tick the concept if the answer is "yes, " if not leave that line blank. Circle one of the four categories in the third column. Do not work too fast and be conscientious; this is not a test, but a determination of where you stand.

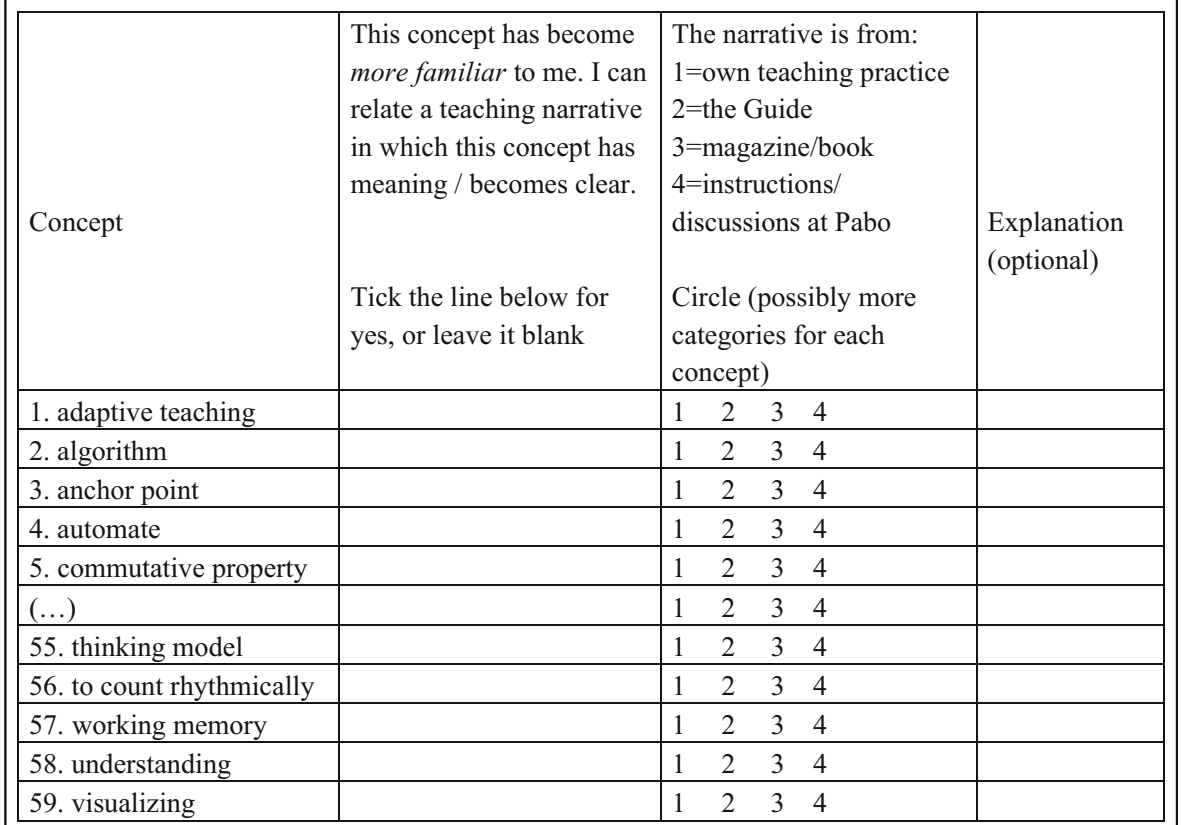


Open Access This article is distributed under the terms of the Creative Commons Attribution 4.0 International License (http://creativecommons.org/licenses/by/4.0/), which permits unrestricted use, distribution, and reproduction in any medium, provided you give appropriate credit to the original author(s) and the source, provide a link to the Creative Commons license, and indicate if changes were made.

\section{References}

Akkerman, S., \& Bakker, A. (2011). Boundary crossing and boundary objects. Review of Educational Research, 81, 132-169. https://doi.org/10.3102/0034654311404435.

Ausubel, D. P. (1968). Educational psychology: a cognitive view. New York: Holt, Rinehart \& Winston.

Bakhtin, M. M. (1981). The dialogic imagination: four essays (C. Emerson \& M. Holquist, Trans.). M. Holquist (Ed.). Austin: University of Texas Press.

Bales, R. F. (1951). Interaction process analysis: a method for the study of small groups. Cambridge: Addison-Wesley Press.

Ball, D. L. (2000). Bridging practices: intertwining content and pedagogy in teaching and learning to teach. Journal of Teacher Education, 51(3), 241-247. https://doi.org/10.1177/0022487100051003013.

Ball, D. L., Hill, H. C., \& Bass, H. (2005). Knowing mathematics for teaching: who knows mathematics well enough to teach third grade, and how can we decide? American Educator, 29, 14-22 43-46.

Ball, D. L., Thames, M. H., \& Phelps, G. (2008). Content knowledge for teaching: what makes it special? Journal of Teacher Education, 59(5), 389-407. https://doi.org/10.1177/0022487108324554.

Borko, H. (2016). Methodological contributions to video-based studies of classroom teaching and learning: a commentary. ZDM Mathematics Education, 48(1-2), 213-218. https://doi.org/10.1007/s11858-0160776-x.

Brophy, J. (Ed.). (2004). Advances in research on teaching: using video in teacher education (Vol. 10). New York: Elsevier Science.

Clandinin, D. J., \& Connelly, F. M. (1996). Teachers' professional knowledge landscapes: teacher storiesstories of teachers - school stories - stories of schools. Educational Researcher, 25(3), 24-30. https://doi. org/10.3102/0013189X025003024.

Clark, C. M., \& Lampert, M. (1986). The study of teacher thinking: implications for teacher education. Journal of Teacher Education, 37(5), 27-31. https://doi.org/10.1177/002248718603700506.

Cobb, P. (1988). The tension between theories of learning and instruction in mathematics education. Educational Psychologist, 23(2), 87-103. https://doi.org/10.1207/s15326985ep2302 2.

Cobb, P., Confrey, J., diSessa, A., Lehrer, R., \& Schauble, L. (2003). Design experiments in educational research. Educational Researcher, 32(1), 9-13. https://doi.org/10.3102/0013189X032001009.

Cochran-Smith, M., \& Lytle, S. L. (1999). Relationships of knowledge and practice: teacher learning in communities. Review of Research in Education, 24, 249-306. https://doi.org/10.2307/1167272.

Cohen, J. (1960). A coefficient of agreement for nominal scales. Educational and Psychological Measurement, 20(1), 37-46. https://doi.org/10.1177/001316446002000104.

Cohen, D. K. (2011). Teaching and its predicaments. Cambridge: Harvard University Press. https://doi. org/10.4159/harvard.9780674062788.

Da Ponte, J. P. (2013). Theoretical frameworks in researching mathematics teacher knowledge, practice, and development. Journal of Mathematics Teacher Education, 16, 319-322. https://doi.org/10.1007/s10857013-9249-0.

Dewey, J. (1904). The relation of theory to practice in education. In C. A. McMurry (Ed.), The third yearbook of the National Society for the Scientific Study of Education. Part I: The relation of theory to practice in the education of teachers (pp. 9-30). Chicago: University of Chicago Press https://archive.org/details/r00 elationoftheorynatirich/.

Dick, T. P., \& Hollebrands, K. F. (2011). Focus in high school mathematics: technology to support reasoning and sense making. Reston: NCTM.

Dolk, M., Faes, W., Goffree, F., Hermsen, H., \& Oonk, W. (1996). A multimedia interactive learning environment for (future) primary school teachers with content for primary mathematics teacher education programs. Utrecht, the Netherlands: Freudenthal Institute/National Association for the Development of Mathematics Education.

Drijvers, P. (2019). Embodied instrumentation: combining different views on using digital technology in mathematics education. In U. T. Jankvist, M. van den Heuvel-Panhuizen, \& M. Veldhuis (Eds.), Proceedings of the Eleventh Congress of the European Society for Research in Mathematics 
Education. Utrecht, the Netherlands: Freudenthal Group \& Freudenthal Institute, Utrecht University and ERME.

Elbaz, F. (1981). The teacher's "practical knowledge": report of a case study. Curriculum Inquiry, 11(1), 4371. https://doi.org/10.2307/1179510.

Freudenthal, H. (1973). Mathematics as an educational task. Dordrecht, the Netherlands: Reidel.

Freudenthal, H. (1983). Didactical phenomenology of mathematical structures. Dordrecht: Reidel.

Freudenthal, H. (1987). Theorievorming bij het wiskundeonderwijs. Geraamte en gereedschap [Formation of theory in mathematics education. Framework and tools]. Tijdschrift voor nascholing en onderzoek van het reken-wiskundeonderwijs, 5(3), 4-15.

Freudenthal, H. (1991). Revisiting mathematics education: China lectures. Dordrecht, the Netherlands: Kluwer Academic Publishers.

Gaudin, C., \& Chaliès, S. (2015). Video viewing in teacher education and professional development: a literature review. Educational Research Review, 16, 41-67. https://doi.org/10.1016/j.edurev.2015.06.001.

Goffree, F., \& Dolk, M. (Eds.). (1995). Standards for mathematics education (R. Rainero, Trans.)[translation of a portion of F. Goffree \& M. Dolk (Eds.). (1995). Proeve van een nationaal programma voor rekenenwiskunde \& didactiek op de Pabo]. Utrecht, the Netherlands: NVORWO/ SLO. Retrieved from http://www.fi.uu.nl/publicaties/literatuur/1063.pdf

Goffree, F., \& Oonk, W. (1999). Teacher education around the world. Educating primary school mathematics teachers in the Netherlands: back to the classroom. Journal of Mathematics Teacher Education, 2(2), 207-214. https://doi.org/10.1023/A:1009903205316.

Goffree, F., \& Oonk, W. (2001). Digitizing real practice for teacher education programmes: the MILE approach. In F.-L. Lin \& T. J. Cooney (Eds.), Making sense of mathematics teacher education (pp. 111-145). Dordrecht, the Netherlands: Kluwer Academic Publishers. https://doi.org/10.1007/978-94-0100828-0_6.

Goffree, F., Markusse, A., Munk, F., \& Olofsen, K. (2003). Gids voor rekenen/wiskunde. Verhalen uit groep 4, versie 2003 [Guide for mathematics. Stories from grade 2, version 2003]. Groningen, the Netherlands: Wolters-Noordhoff.

Goldman, R. P., Barron, B., \& Derry, S. (Eds.). (2007). Video research in the learning sciences. Mahwah: Lawrence Erlbaum.

Goos, M., \& Bennison, A. (2018). Boundary crossing and brokering between disciplines in pre-service mathematics teacher education. Mathematics Education Research Journal, 30, 255-275. https://doi. org/10.1007/s13394-017-0232-4.

Gravemeijer, K. P. E. (2004). Local instruction theories as a means of support for teachers in reform mathematics education. Mathematical Thinking and Learning, 6(2), 105-128. https://doi.org/10.1207 /s15327833mt10602_3.

Gravemeijer, K. (2008). RME theory and mathematics teacher education. In D. Tirosh \& T. Wood (Eds.), Tools and processes in mathematics teacher education (pp. 283-302).

Gravemeijer, K., Stephan, M., Julie, C., Lin, F., \& Ohtani, M. (2017). What mathematics education may prepare students for the society of the future? International Journal of Science and Mathematics Education, 15(Suppl 1), S105-S123. https://doi.org/10.1007/s10763-017-9814-6.

Grossman, P., Compton, C., Igra, D., Ronfeldt, M., Shahan, E., \& Williamson, P. W. (2009). Teaching practice: a cross-professional perspective. Teachers College Record, 111(9), 2055-2100.

Herbst, P., Chazan, D., Chen, C.-L., Chieu, V.-M., \& Weiss, M. (2011). Using comics-based representations of teaching, and technology, to bring practice to teacher education courses. ZDM-The International Journal on Mathematics Education, 43(1), 91-103. https://oi.org/10.1007/s11858-010-0290-5.

Jacobs, V. R., Lamb, L. L. C., \& Philipp, R. A. (2010). Professional noticing of children's mathematical thinking. Journal for Research in Mathematics Education, 41(2), 169-202.

Jaworski, B. (2006). Theory and practice in mathematics teaching development: critical inquiry as a mode of learning in teaching. Journal of Mathematics Teacher Education, 9(2), 187-211. https://doi.org/10.1007 /s10857-005-1223-z.

Kaiser, B., Schwarz, B., \& Krackowitz, S. (2007). The role of beliefs on future teacher's professional knowledge [Monograph]. The Montana Mathematics Enthusiast, 3, 99-116.

Kang, H., \& van Es, E. A. (2018). Articulating design principles for productive use of video in preservice education. Journal of Teacher Education. https://doi.org/10.1177/0022487118778549.

Keijzer, R., \& Kool, M. (2012). Mathematical knowledge for teaching in the Netherlands. Paper presented at the 12th International Conference on Mathematics Education, Seoul, South Korea. Retrieved from http://dspace.library.uu.nl/handle/1874/272294

Kilpatrick, J., Swafford, J., \& Findell, B. (Eds.). (2001). Adding it up: helping children learn mathematics. Washington, DC: National Academy Press. 
Korthagen, F. A. J. (2001). Linking theory and practice: the pedagogy of realistic teacher education. Mahwah: Lawrence Erlbaum Publishers.

Korthagen, F. A. J. (2010). How teacher education can make a difference. Journal of Education for Teaching: International Research and Pedagogy, 36(4), 407-423. https://doi.org/10.1080/02607476.2010.513854.

Krippendorff, K. (2004). Content analysis: an introduction to its methodology (2nd ed.). Thousand Oaks: Sage.

Lampert, M. (2001). Teaching problems and the problems of teaching. New Haven: Yale University Press. https://oi.org/10.1023/A:1015870009117.

Lampert, M. (2010). Learning teaching in, from, and for practice: what do we mean? Journal of Teacher Education, 61(1-2), 21-34. https://doi.org/10.1177/0022487109347321.

Lampert, M., \& Ball, D. L. (1998). Teaching, multimedia, and mathematics: investigations of real practice. New York: Teachers College Press.

Lave, J. (1996). Teaching, as learning, in practice. Mind, Culture, and Activity, 3, 149-164. https://doi. org/10.1207/s15327884mca0303_2.

Leikin, R., \& Levav-Waynberg, A. (2007). Exploring mathematics teacher knowledge to explain the gap between theory-based recommend dations and school practice in the use of connecting tasks. Educational Studies in Mathematics, 66, 349-371. https://doi.org/10.1007/s10649-006-9071-z.

Lerman, S. (2013). Theories in practice: mathematics teaching and mathematics teacher education. ZDM-The International Journal on Mathematics Education, 45(4), 623-631. https://doi.org/10.1007/s11858-0130510-x.

Lin, P.-J. (2002). On enhancing teachers' knowledge by constructing cases in classrooms. Journal of Mathematics Teacher Education, 5(4), 317-349. https://doi.org/10.1023/A:1021282918124.

Masingila, J. O., \& Doerr, H. M. (2002). Understanding pre-service teachers' emerging practices through their analyses of a multimedia case study of practice. Journal of Mathematics Teacher Education, 5(3), 235263. https://doi.org/10.1023/A:1019847825912.

Mor, Y., \& Noss, R. (2008). Programming as mathematical narrative. International Journal of Continuing Engineering Education and Life-Long Learning (IJCEELL), 18(2), 214-233. https://doi.org/10.1504 /IJCEELL.2008.017377.

Morris, A. K., Hiebert, J., \& Spitzer, S. M. (2009). Mathematical knowledge for teaching in planning and evaluating instruction: what can pre-service teachers learn. Journal for Research in Mathematics Education, 40(5), 491-529.

National Council of Teachers of Mathematics. (2000). Principles and standards for school mathematics. Reston: Author.

National Council of Teachers of Mathematics. (2015). Strategic use of technology in teaching and learning mathematics. A position of the National Council of Teachers of Mathematics. Reston: Author.

Nunes, T., Vargas Dorneles, B., Lin, P., \& Rathgeb-Schnierer, E. (2016). Teaching and learning about whole numbers in primary school, ICME-13 Topical Surveys. https://doi.org/10.1007/978-3-319-45113-8_1

Oonk, W., \& De Goeij, E. T. J. (2006). Wiskundige attitudevorming [Educating a Mathematics Attitude]. Tijdschrift voor nascholing en onderzoek van het reken-wiskundeonderwijs, jaargang, 25(4), 37-39.

Oonk, W., Goffree, F., \& Verloop, N. (2004). For the enrichment of practical knowledge: good practice and useful theory for future primary teachers. In J. Brophy (Ed.), Advances in research on teaching: using video in teacher education (Vol. 10, pp. 131-168). New York: Elsevier Science. https://doi.org/10.1016 /S1479-3687(03)10006-5.

Oonk, W., van Zanten, M., \& Keijzer, R. (2007). Gecijferdheid, vier eeuwen ontwikkeling: Perspectieven voor de opleiding [Numeracy, four centuries of development: Perspectives for teacher education]. Rekenwiskundeonderwijs: Onderzoek, Ontwikkeling, Praktijk [Primary Mathematics Education: Research, Development, Practice], 26(3), 3-18.

Oonk, W., Verloop, N., \& Gravemeijer, K. P. E. (2015a). Enriching practical knowledge: exploring student teachers' competence in integrating theory and practice of mathematics teaching. Journal for Research in Mathematics Education, 46(5), 559-598. https://doi.org/10.5951/jresematheduc.46.5.0559.

Oonk, W., Keijzer, R., Lit, S., Barth, F., Den Engelsen, J. F. M., Lek, A. T. E., \& Van Waveren Hogervorst, C. (2015b). Rekenen-wiskunde in de praktijk-Kerninzichten [Mathematics in practice: Big ideas] (2nd ed.). Groningen, the Netherlands: Noordhoff Uitgevers bv.

Oonk, W., Keijzer, R., Lit, S., \& Barth, F. (2017). Rekenen-wiskunde in de praktijk-Verschillen in de klas. [Mathematics in practice: Differences in class] (2nd ed.). Groningen, the Netherlands: Noordhoff Uitgevers bv.

Oonk, W., Keijzer, R., \& Van Zanten, M. (2019). Mathematics \& didactics as a subject in primary school teacher education in the Netherlands. In M. Van den Heuvel-Panhuizen, P. Drijvers, M. Doorman, \& M. 
Van Zanten (Eds.), Reflections from inside on the Netherlands Didactic Tradition in Mathematics Education. Utrecht: Freudenthal Institute, Utrecht University.

Pendlebury, S. (1995). Reason and story in wise practice. In H. McEwan \& K. Egan (Eds.), Narrative in teaching, learning and research (pp. 50-65). New York: Teachers College Press.

Piaget, J. (1974). La prise de conscience [The grasp of consciousness]. Paris: Presses Universitaires de France.

Putnam, R. T., \& Borko, H. (1997). Teacher learning: implications of new views of cognition. In B. Biddle, T. L. Good, \& I. F. Goodson (Eds.), International handbook of teachers and teaching (Vol. II, pp. 12231296). Dordrecht: Kluwer Academic Publishers.

Ruthven, K. (2001). Mathematics teaching, teacher education, and educational research: developing "practical theorizing" in initial teacher education. In F. Lin \& T. Cooney (Eds.), Making sense of mathematics teacher education. Dordrecht, the Netherlands: Kluwer Academic Publishers. https://doi.org/10.1007 /978-94-010-0828-0 8.

Ruthven, K. (2011). Conceptualising mathematical knowledge in teaching. In T. Rowland \& K. Ruthven (Eds.), Mathematical knowledge in teaching. Dordrecht, the Netherlands: Springer. https://doi. org/10.1007/978-90-481-9766-8_6.

Ryve, A. (2011). Discourse research in mathematics education: a critical evaluation of 108 journal articles. Journal for Research in Mathematics Education, 42(2), 167-198.

Schack, E. O., Fisher, M. H., Thomas, J. N., Eisenhardt, S., Tassell, J., \& Yoder, M. (2013). Prospective elementary school teachers' professional noticing of children's early numeracy. Journal of Mathematics Teacher Education, 16(5), 379-397. https://doi.org/10.1007/s10857-013-9240-9.

Schön, D. A. (1983). The reflective practitioner: how professionals think in action. New York: Basic Books.

Sfard, A. (2008). Thinking as communicating: human development, the growth of discourses, and mathematizing. Cambridge: Cambridge University Press. https://doi.org/10.1017/CBO9780511499944.

Sherin, M. G., \& Dyer, E. B. (2017). Mathematics teachers' self-captured video and opportunities for learning. Journal of Mathematics Teacher Education, 20, 477. https://doi.org/10.1007/s10857-017-9383-1.

Shulman, L. S. (1986). Those who understand: knowledge growth in teaching. Educational Researcher, 15(2), 4-14. https://doi.org/10.3102/0013189X015002004.

Silver, E. A., \& Herbst, P. G. (2007). Theory in mathematics education scholarship. In F. K. Lester Jr. (Ed.), Second handbook of research on mathematics teaching and learning (Vol. 1, pp. 39-67). Charlotte: Information Age Publishing.

Simon, M. A. (1995). Reconstructing mathematics pedagogy from a constructivist perspective. Journal for Research in Mathematics Education, 26(2), 114-145. https://doi.org/10.2307/749205.

Skott, J., Van Zoest, L., \& Gellert, U. (2013). Theoretical frameworks in research on and with mathematics teachers. ZDM-The International Journal on Mathematics Education, 45(4), 501-505. https://doi. org/10.1007/s11858-013-0509-3.

Smit, J., Bakker, A., Van Eerde, D., \& Kuijpers, M. (2016). Using genre pedagogy to promote student proficiency in the language required for interpreting line graphs. Mathematics Education Research Journal, 28, 457. https://link.springer.com/article/10.1007/s13394-016-0174-2.

Sriraman, B., \& Kaiser, G. (2006). Theory usage and theoretical trends in Europe: a survey and preliminary analysis of CERME4 research reports. ZDM-The International Journal on Mathematics Education, 38(1), 22-51. https://doi.org/10.1007/BF02655904.

Stigler, J. W., \& Hiebert, J. (1999). The teaching gap: best ideas from the world's teachers for improving education in the classroom. New York: Free Press.

Stockero, S. L. (2008). Using a video-based curriculum to develop a reflective stance in prospective mathematics teachers. Journal of Mathematics Teacher Education, 11(5), 373-394. https://doi. org/10.1007/s10857-008-9079-7.

Ter Heege, H. (1985). The acquisition of basic multiplication skills. Educational Studies in Mathematics, 16(4), 375-388. https://doi.org/10.1007/BF00417193.

Treffers, A. (1987). Three dimensions. A model of goal and theory description in mathematics education-the Wiskobas project. Dordrecht, the Netherlands: Kluwer Academic Publishers.

Van den Heuvel-Panhuizen, M. (Ed.). (2001). Children learn mathematics: a learning-teaching trajectory with intermediate attainment targets for calculation with whole numbers in primary school. Utrecht, the Netherlands: Freudenthal Institute.

Van Es, E. A., \& Sherin, M. G. (2010). The influence of video clubs on teachers' thinking and practice. Journal of Mathematics Teacher Education, 13, 155-176. https://doi.org/10.1007/s10857-009-9130-3.

Van Hiele, P. M. (1973). Begrip en inzicht. Werkboek van de wiskundedidaktiek [Understanding and insight. Workbook of mathematics pedagogy]. Purmerend, the Netherlands: Muusses.

Van Hiele, P. M. (1986). Structure and insight. A theory of mathematics education. Orlando: Academic Press. 
Vergnaud, G. (1983). Multiplicative structures. In R. Lesh \& M. Landau (Eds.), Acquisition of mathematics concepts and processes (pp. 128-174). New York: Academic Press.

Verloop, N. (2001). Guest editor's introduction. International Journal of Educational Research, 35(5), 435440. https://doi.org/10.1016/S0883-0355(02)00002-2.

Verloop, N., Van Driel, J., \& Meijer, P. (2001). Teacher knowledge and the knowledge base of teaching. International Journal of Educational Research, 35(5), 441-461. https://doi.org/10.1016/S0883-0355(02 )00003-4.

Vescio, V., Ross, D., \& Adams, A. (2008). A review of research on the impact of professional learning communities on teaching practice and student learning. Teaching and Teacher Education, 24, 80-91. https://doi.org/10.1016/j.tate.2007.01.004.

Zeichner, K. M., Tabachnick, B. R., \& Densmore, K. (1987). Individual, institutional, and cultural influences on the development of teachers' craft knowledge. In J. Calderhead (Ed.), Exploring teachers' thinking (pp. 21-59). London: Cassell.

Publisher's note Springer Nature remains neutral with regard to jurisdictional claims in published maps and institutional affiliations.

\section{Affiliations}

\section{Wil Oonk ${ }^{1} \cdot$ Nico Verloop $^{2} \cdot$ Koeno P. E. Gravemeijer ${ }^{3}$}

1 Freudenthal Institute, Utrecht University, Orionlaan 96, 1223 AK Hilversum, the Netherlands

2 ICLON Graduate school of Teaching, Leiden University, Postbox 905, 2300 AX Leiden, the Netherlands

3 Eindhoven University of Technology, Rijnsburgweg 47, 2334 BG Leiden, the Netherlands 